says there would not be enough work for a full-time ultrasonics expert, recommended by the committee for testing pressure vessels, and that this and other work will be contracted out when it lacks the appropriate experts on its own staff.

The inspectorate is nevertheless still short of nuclear inspectors. Thirteen posts out of a total of 102 remain to be filled and salaries are a problem. Although nuclear inspectors' pay is as good as or better than that of other inspectors, it is below that in the industries from which it has to recruit. The problem - that the inspectors' salaries are linked to civil service pay - cannot be solved by removing the inspectorate from the Health and Safety Executive, which the inspectorate says would complicate licensing procedures.

The committee is said also to have misunderstood the role of the chief scientist at the Department of Energy and of the UK Atomic Energy Authority in advising the government on nuclear matters. The Department of Energy says that its chief scientist is responsible for nuclear advice but that there were exceptions when Dr Walter Marshall held

\section{Authority more critical}

The United Kingdom Atomic Energy Authority made a forceful response last week to the critical report of the House of Commons Select Committee on Energy (see Nature 19 February, p.621) Dr Walter Marshall, the bulky and voluble Welshman who succeeded Sir John Hill as chairman at the weekend, was quickly in action with his account of where the select committee had gone wrong.

The committee's wrath was directed chiefly at the Central Electricity Generating Board, but it also asked that the authority's role in the development of

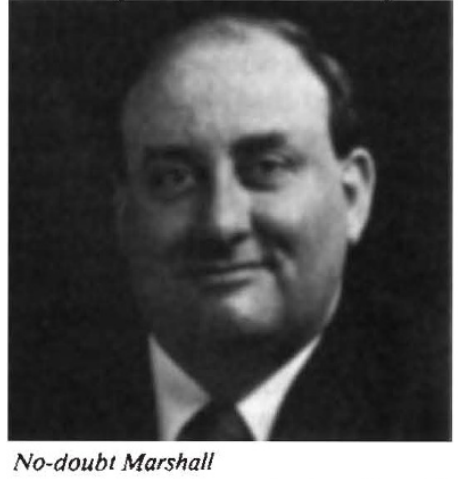

nuclear power in Britain should be restricted to research on long-term projects (fast reactors and fusion devices) and others where interested parties chose to commission work.

Marshall argues that this conclusion is mistaken. Thus he justifies the authority's work on the safety of pressurized water reactors (now costing $£ 10$ million a year) on the grounds that the authority is more independent than the would-be builders of the plant, the the post as well as that of deputy chairman of the UK Atomic Energy Authority. Dr Marshall's version of this difficulty is different. He said last week that during his spell as chief scientist at the department, he felt no conflict of interest but, with the minister's agreement, meticulously kept the chairman of the authority informed of the advice he gave on nuclear matters.

The response so far to the report has been laconic and avoids detail. A more considered reply is likely to be published by the Department of Energy some months from now. Another contribution is likely to come from the Monopolies and Mergers Commission when it makes its views known on the structure of the electricity supply industry on 2 March.

Judy Redfearn

\section{UK science research On the move}

The Science Research Council's attempt to foster mobility among British academics has made a modest beginning. The first four awards under the council's Special

generating board, and less likely to continue indefinitely in the field than, say, the Nuclear Installations Inspectorate.

On the select committee's opinion that the authority should not be the public shareholder in the National Nuclear Corporation, the publicly supported construction consortium, Marshall says that the only effect of such a change would be to replace him by a civil servant as a director of the corporation. At present, he says, the authority's representation is the only source of independent criticism on the board.

The recommendation that the authority should quickly make an assessment of the Canadian CANDU heavy-water reactor system is similarly unwelcome. Marshall says that the committee has underestimated the difficulty of adapting even wellestablished reactor systems to British safety regulations, and estimates that a proper assessment would require two years of hard work. He points out that the select committee overlooked the authority's role in the development and management of the nuclear fuel cycle.

Dr Marshall's succession as chairman of the authority - he has been waiting in the wings for several years - presages a change of style. He is both outspoken and ebullient. He has his roots in the research establishment at Harwell (where he will keep an office). Last week he was saying that there will be no cause for changing the role of the authority until fast reactors are commercial realities some time in the next century. But he plans that the authority should become more skilled at explaining what it is about.
Replacement Scheme were announced last week. The scheme is designed to release senior academics from routine duties for five years, replacing them with younger people, usually postdoctoral researchers. The four awards will be followed by a further eleven before July, after which the council hopes to make ten awards a year.

The first four awards go to people who will be released from some or all of their administrative and teaching commitments for up to five years, enabling them to concentrate on their research interests. Each of the four departments is advertising a vacancy for a lecturer, whose appointment will be financed wholly by the Science Research Council for the first five years of his tenure. In every other respect, however, those appointed will be fullyfledged members of the academic staff.

Here the similarity ends. Some of the senior academics will return to their original position after five years. During that time, the department, which has guaranteed tenure to the new appointee, will have either found money elsewhere or lost a member of staff (by foul means or, more probably, fair). In other cases, the senior person will himself be retiring.

The Science Research Council, which has designed the scheme for flexibility, makes no stipulation about the areas of research involved, although it does intend to be represented on the selection boards for new appointees. In the cases so far announced, one professor should gain a member of staff in his own field of research, while another's department is to advertise for applicants for any of its research areas. Much discussion takes place behind the scenes between the council and the university concerned, and Sir Harry Pitt (ex-vice-chancellor of the University of Reading) is go-between and honest broker for the scheme.

The Science Research Council, through its boards and subcommittees which allocate grants among the applicants (30 of whom are now being considered), hopes to ease stagnation in research areas that it feels deserve encouragement. Awards have been given to Professors D. H. Everett (physical chemistry, Bristol), J. G. Powles (physics, Kent), M. Symons (chemistry, Leicester) and R. Butterfield (civil engineering, Southampton).

Philip Campbell

\section{Community research}

\section{Project sharing?}

\section{Brussels}

The European Parliament has now called for more community research. This arose at a meeting between the Parliament's Science and Energy Committee, the Dutch Minister for Science and Technology, Anton van Trier, and Dr Guenter Schuster, the director general for research, science and education of the European commission. 
Mr van Trier pointed out that between 1970 and 1980 , Community expenditure on research and development had increased by 18 per cent, but that out of the 20,000 million European Units of Account (EUA) $(1 \mathrm{EUA}=£ 0.56)$ which the member states spent on their energy and research programmes in 1980 , only 1.5 per cent was spent jointly. The president of the committee, Hanna Walz, while endorsing $\mathrm{Mr}$ Van Trier's affirmation of the significance of Community research, pointed out that there is a considerable gap between the declared intentions of the Council of Ministers and its actions.

Other members of the committee thought that the time was ripe to set in motion a "real Community research policy", since major areas could not be adequately tackled by each country on its own. Dr Schuster said that Community research would continue to concentrate on specific areas, particularly nuclear power, energy and environment, and pointed out that the Community contribution in these areas is 30 per cent, 10 per cent and 20 per cent respectively of total Community spending.

$\mathrm{Mr}$ van Trier and the committee agreed that a European market should be created for micro-electronic components and products, but that coordinating national programmes would only be feasible for large projects. The companies themselves must establish relations in order to coordinate the proposed research programmes.

Jasper Becker

\section{US Cabinet appointments}

\section{Conservatives in}

\section{Washington}

One of the few bright spots for US environmentalists in the Cabinet appointments has been Mr Reagan's nomination of $\mathrm{Mr}$ James Buckley, a member of the US Senate from 1971 to 1977, as Under-Secretary of State for National Security, Science and Technology. If confirmed by the Senate, Mr Buckley will be directly responsible for the State Department's Bureau of Oceans and International Environmental and Scientific Affairs. Under a reorganization plan being discussed in the White House, the bureau may also be given responsibility for nuclear non-proliferation policy.

Mr Buckley is a conservative Republican. He voted against the War Powers Act giving Congress greater control over presidential decisions, and also opposed the first Strategic Arms Limitation Treaty (SALT), because it limited the United States to the construction of only two anti-ballistic missile sites - which were never built.

As a member of the Senate's environmental pollution subcommittee and its environmental science and technology subcommittee, Mr Buckley helped to forge much of the stringent environmental legislation of the 1970s. He clearly intends to take a close personal interest in environmental issues in his new post. High on his agenda is discussion with Canada of the effects of acid rain from the north-east states. Another issue is international attempts to prevent the extinction of endangered species; Mr Buckley told his nomination hearing in the Senate last week that "as a friend of the snail darter [whose potential extinction was used to hold up a federal dam project] I look forward to extending my responsibilities",

One potential dispute has already been headed off by the State Department. In its preliminary proposals for budget cuts, the Office of Management and Budget had suggested eliminating the $\$ 10$ million contributed by the United States to the United Nations Environment Programme (UNEP). This - almost a third of the agency's budget - would have devastated UNEP's future programmes, but was successfully resisted by $\mathrm{Mr}$ Haig, and a contribution of $\$ 7.2$ million is being proposed. In his Senate hearing, $\mathrm{Mr}$ Buckley said this would be "foolhardy".

Nuclear non-proliferation policy will be more difficult to deal with but will be high on the new Administration's agenda, since India is already preparing to make a further application for the export of enriched uranium to its Tarapur nuclear plant. $\mathrm{Mr}$ Buckley told the Senate Foreign Relations Committee that the Reagan Administration was completely reviewing non-proliferation strategy.

Mr Buckley, who ran for the Senate in Connecticut, had been tipped as the new administrator of the Environmental Protection Agency. In fact, the White House announced last week the nomination of a Colorado attorney, Mrs Anne Gorsuch, a close political ally of Interior Secretary James Watt, to head the agency. Both nominations have generated protests from environmentalists.

David Dickson

\section{UK medical research}

\section{Money to spend}

A $£ 350,000$ windfall has landed in the hands of the British Medical Research Council's Laboratory of Molecular Laboratory, Cambridge. The money was donated quite unexpectedly by $\mathrm{Mr}$ Thomas Usher, chairman of the Canadian company, Dextran. Since Mr Usher first approached the laboratory last May, a fund has been set up to support research fellows and students over the next seven years.

The offer of money comes with no strings attached, and the company had previously had only brief contact with the laboratory - many years ago Dr Max Perutz gave Mr Usher some advice.

The staff of the laboratory has agreed with Mr Usher that the money should be used to support research staff, the most serious hole left by cuts in the Medical
Research Council's budget. The resulting fund will provide $£ 50,000$ a year for one to three-year fellowships, short fellowships for visiting scientists and studentships over the next seven years.

The scheme is to get under way in earnest next October. The trustees of the fund Drs Sydney Brenner, director of the laboratory, Frederick Sanger, John Gurdon, Hugh Huxley and Aaron Klug will decide on the next recipients in June.

Judy Redfearn

\section{High-energy physics}

\section{China backs off}

\section{Washington}

Economic problems have forced the People's Republic of China to postpone construction of a $50 \mathrm{GeV}$ particle accelerator scheduled to be built near the Ming Tombs, north-west of Peking.

The accelerator, to have been built with the assistance of the US Department of Energy, was central to the agreement between China and the United States signed by President Carter and VicePremier Deng Xiao Ping in Washington two years ago.

US of ficial who visited China last month were told that although construction was being deferred as part of a major cutback in capital construction projects, the delay did not imply a reduced commitment to research and training in advanced science and technology. The officials feel, however, that a "softening" in China's previous commitment to high-energy physics is inevitable.

Under the agreement, the Department of Energy would have carried out much of the construction of the components of the accelerator, receiving purchase orders over a period of five years of between $\$ 100$ and $\$ 200$ million for work that would have been carried out at the national energy laboratories. Subsequently the terms were changed so that the Chinese would carry out most of the design and construction work, and the United States would only provide basic training and advice.

The Chinese have also told the National Aeronautics and Space Administration that they will have to postpone the planned purchase of a new US-built telecommunications satellite system, another major component of the science and technology agreement. Four major contractors had already discussed with the Chinese the specifications of such a system, and were preparing bids. In a letter, the head of the Chinese academy of space technology, Dr Ran Xin-Mon, has now said that China was being forced to reconsider the whole of its space programme in the light of its economic situation.

China is, however, continuing negotiations over the purchase of equipment to receive geophysical information from the LANDSAT remote sensing satellite. It has 